\title{
Index of Stimulation and TNF $\alpha$ Measurements Used for laboratory Diagnosis of Latent Tuberculosis as a New Principle
}

Sándor Sipka ${ }^{1 *}$, Zsuzsánna Papp ${ }^{2}$, Ildikó Kovács ${ }^{1}$, Kata Horváti $^{3}$, Szilvia Bősze ${ }^{3}$, Ferenc Hudecz ${ }^{3}$ and Mária Szilasi ${ }^{2}$

${ }^{1}$ Division of Clinical Immunology, Department of Internal Medicine, Faculty of Medicine, University of Debrecen, Debrecen, Hungary.

${ }^{2}$ Department of Pulmonology, Faculty of Medicine, University of Debrecen, Debrecen, Hungary.

${ }^{3}$ MTA-ELTE Research Group of Peptide Chemistry, Hungarian Academy of Sciences, Loránd Eötvös University, Budapest, Hungary.

Received: 09 August, 2018; Accepted: 09 September, 2018; Published: 17 September, 2018

*Corresponding author: Sándor SIPKA MD, Division of Clinical Immunology, University of Debrecen, 4032 Debrecen, Móricz Zsigmond str. 22, Hungary. Tel/Fax: 36, 52, 255-218; E-mail: sipka@iiibel.dote.hu.

\begin{abstract}
A new principle of a method for the laboratory diagnosis of latent Mycobacterium tuberculosis infection (LBTI) compared to the QuantiFERON (QFT) test is presented. The new elements, the calculation and introduction of an Index of Stimulation (IS) were based on the measurements of tumour necrosis- $\alpha$ (TNF- $\alpha$ ) release in whole human blood stimulated by the peptides (TB-P) derived from Mycobacterium tuberculosis (Mtb) related proteins and Purified Protein Derivative (PPD). The amount of TNF- $\alpha$ was determined by ELISA. The calculation of IS values was carried by the formula: TNF$\alpha(\mathrm{pg} / \mathrm{ml})$ TB-P/ TNF- $\alpha(\mathrm{pg} / \mathrm{ml}) P P D$. The populations studied consisted of a) 15 healthcare workers dealing with Mtb-infected patients (HCWTB); b) 14 healthcare workers not being exposed to Mtb patients (HCW-C) as controls. The diagnosis of LTBI was established if IS was higher than 1.50. In the HCW-TB group the number of LTBI was 6/15 by the new method and $9 / 15$ by QFT. Tested clinically, the number of false-positive results by QFT was 3/9. All members of HCW-C group were LTBI negative by both methods. This new assay did not result in any false positive reactions. Although these results are still preliminary data derived from few patients. However, the theoretical novelties in the principle of method: the calculation of IS from the TNF- $\alpha$-TB-P/ TNF- $\alpha-P P D$ values can mean a progress in the individual laboratory diagnosis of LTBI in further studies.
\end{abstract}

Key words: Latent tuberculosis; QuantiFERON-TB; tumour necrosis factor $-\alpha$; TNF- $\alpha$ - IS;

\section{Introduction}

A great number of studies have been reported on markers that can differentiate between active tuberculosis disease (TB) caused by Mycobacterium tuberculosis (Mtb) and latent tuberculosis infection (LTBI) from the "clinically" healthy population [1]. The disease affects both Bacillus Calmette-Guérin (BCG)-vaccinated and non-vaccinated people and susceptibility to infection and disease is related to decreased host immunity. Traditionally, the diagnosis of LTBI has relied on the tuberculin skin test (TST, Mantoux reaction) [2]. However, it has several limitations, including a high rate of false-positive results among individuals vaccinated with BCG or exposed to non-TB Mycobacteria [3].
Genome driven advances in Mtb antigen discovery have identified antigens that are absent from the $M$. bovis BCG. These antigens are encoded by open reading frames distributed in 12 regions of difference (RD) on the MTB chromosome, and offer the advantage to distinguish between infection and prior vaccination with BCG. RD1 based ESAT-6 (Rv3875) and CFP-10 (Rv3874), both of which form the basis of the two recently commercialised immunodiagnostic tests: T-SPOT.TB and QuantiFERON-TB-Gold [4-7]. Regardless of their reported sensitivities, the T-cell based Interferon $\gamma$ (IFN $\gamma$ ) Release Assays (IGRAs) are dominating for the diagnosis of LTBI [7-9]. Typically, cocktails of ESAT-6, CFP-10 and peptide 38-55 from TB.7.7 (Rv2654c) derived from M. tuberculosis have been applied in these measurements to stimulate the peripheral mononuclear cells to produce antigen specific release of IFN $\gamma$.

However, the two types of commercially available IGRA tests:

a) "QuantiFERON-TB Gold In Tube (QFT" and

b) "TSPOT.TB" have not shown sufficient diagnostic accurateness $[7,10]$

"Currently, there is no gold standard for TB screening and the most-used diagnostic tools show low agreement"[11]. However, it is also true that there are new efforts to identify the potential biomarkers from the supernatants of samples of IGRA test. It became apparent from these studies that among the great number of newly identified compounds and the "classic" biomarker (IFN $\gamma$ ), tumour necrosis alpha (TNF- $\alpha$ ) was always detectable as one of the key molecules for Mycobacterial dormancy and host responses in tuberculosis [12-16].

In the current work we report on the calculation and introduction of a stimulation test with Mycobacterium related peptides including three basic modifications:

a) Using TNF- $\alpha$ measurements instead of IFN $\gamma$.

b) Evaluating the stimulating effect of a synthetic peptide mixture (TB-P) in comparison to "Purified Protein Derivative" (PPD). 
c) Definition and use of an Index of Stimulation (IS) value.

We compared this new type of measurement with QFT focusing on the laboratory verification of LTBI in healthcare workers dealing with TB patients for a long time (HCW-TB), as well as in healthcare workers not being exposed to TB patients as controls (HCW-C). The TB-P cocktail used in this study contained synthetic overlapping peptides derived from ESAT- 6 and CFP-10 proteins applied also in the QFT assay in order to concentrate only on the difference between the cytokines released: TNF- $\alpha$ versus IFN $\gamma$. Since all individuals of the present study have earlier been vaccinated by BCG (derived from Bacillus Mycobacterium bovis), PPD (cell- free purified protein fraction obtained from a human strain of Mycobacterium tuberculosis) was used as the "control" stimulant versus TB-P. PPD was chosen in order to reduce the chance of false positivity compared to the values of stimulation by TB-P. It is known, however, that the previous BCG vaccinations can cause numerous false positive Mantoux reactions induced by PPD [17]. Therefore, in our experimental design we always used also PPD stimulation taking possible to calculate an "Index of Stimulation (IS)". Thus, by the calculation of IS, the non-specific "background" effects of PPD could be eliminated from the specific effects of TB-P.

\section{Materials and Methods}

\section{Synthesis and Chemical Characterization of ESAT- 6 and CFP-10 Peptide Series}

All peptides were synthesized with $\mathrm{Fmoc} / \mathrm{tBu}$ solid phase method using Rink Amide MBHA resin resulting in peptide amide $\mathrm{N}$-terminus. The characterization of the peptides by mass spectrometry and amino acid analysis confirmed the expected composition and their cytotoxicity and stability also were tested [18\&19]. The peptides are presented in Table 1.

\begin{tabular}{|c|c|c|c|c|}
\hline Sequence & Code & $\begin{array}{l}\text { RP-HPLC } \\
\text { retention time } \\
{\left[{\text { [min }]^{\mathrm{a}}}\right.}\end{array}$ & $\begin{array}{l}\mathrm{M}_{\mathrm{av}} \\
\text { calculated/ } \\
\text { measured }^{\mathrm{b}}\end{array}$ & Aminoacid Analysis ${ }^{c}$ \\
\hline${ }^{1}$ MAEMKTDAATLAQEAGNFERISGDL ${ }^{25}$ & $\mathrm{C} 1$ & 28.7 & $\begin{array}{c}2668.9 / \\
2668.4\end{array}$ & $\begin{array}{c}\text { D } 3.49 \text { [3]; T } 1.72 \text { [2]; S } 1.05 \text { [1]; E } 4.20 \text { [4]; } \\
\text { G } 1.93 \text { [2]; A } 5.13 \text { [5]; V } 3.05 \text { [3]; I } 1.05 \text { [1]; L } 1.68 \text { [2]; } \\
\text { F } 0.92 \text { [1]; K } 1.05[1] ; \text { R } 0.80[1]\end{array}$ \\
\hline${ }^{30}$ DQVESTAGSLQGQWRGAAGTAAQAAV 55 & $\mathrm{C} 3$ & 22.4 & $\begin{array}{c}2529.7 / \\
2529.2\end{array}$ & $\begin{array}{c}\text { D } 0.63 \text { [1]; T } 1.95 \text { [2]; S } 1.68 \text { [2]; E } 4.32 \text { [5]; } \\
\text { G 4.18 [4]; A 8.04 [7]; V } 1.86 \text { [2]; L } 0.95 \text { [1]; R } 0.77 \text { [1] }\end{array}$ \\
\hline${ }^{46}$ AAGTAAQAAVVRFQEAANKQKQELD ${ }^{73}$ & $\mathrm{C} 4$ & 26.2 & $\begin{array}{c}2614.9 / \\
2615.1\end{array}$ & $\begin{array}{l}\text { D } 1.99 \text { [2]; T } 0.92 \text { [1]; E } 7.03 \text { [6]; } \\
\text { G } 0.76 \text { [1]; A 8.25 [8]; V 2.08 [2]; L } 1.10[1] \\
\text { F } 1.05 \text { [1]; K } 1.89 \text { [2]; R } 0.89[1]\end{array}$ \\
\hline${ }^{56} \mathrm{AANKQKQELDEISTNIRQAGVQYSR}{ }^{80}$ & $\mathrm{C} 5$ & 24.6 & $\begin{array}{c}2847.1 / \\
2847.3\end{array}$ & $\begin{array}{c}\text { D } 2.79 \text { [3]; T } 1.03 \text { [1]; S } 2.23 \text { [2]; E } 6.22 \text { [6]; } \\
\text { G } 1.27 \text { [1]; A } 3.37 \text { [3]; V } 1.14 \text { [1]; I } 1.73 \text { [2]; L } 1.00 \text { [1]; } \\
\text { Y } 0.83 \text { [1]; K } 1.71 \text { [2]; R } 1.68 \text { [2] }\end{array}$ \\
\hline${ }^{71}$ IRQAGVQYSRADEEQQQALSSQMGF95 & C6 & 22.8 & $\begin{array}{l}2827.1 / \\
2826.8\end{array}$ & $\begin{array}{c}\text { D } 1.36 \text { [1]; S } 2.81 \text { [3]; E } 8.86 \text { [8]; } \\
\text { G } 1.86 \text { [2]; A } 3.27 \text { [3]; V 1.00 [1]; M } 0.55 \text { [1]; I } 0.68 \text { [1]; } \\
\text { L } 1.00 \text { [1]; Y } 0.91[1] ; \text { F } 1.17[1] ; \text { R } 1.45[2]\end{array}$ \\
\hline${ }^{1} \mathrm{MTEQQWNFAGIEAAASAIQG}^{20}$ & E1 & 29.8 & $\begin{array}{l}2122.3 / \\
2122.0\end{array}$ & $\begin{array}{l}\text { D } 1.24 \text { [1]; T } 0.96 \text { [1]; S } 0.96 \text { [1]; E } 5.44 \text { [5]; } \\
\text { G } 1.93 \text { [2]; A } 5.22[5] ; \text { M } 0.56 \text { [1]; I } 1.69 \text { [2]; } \\
\text { F } 1.15 \text { [1]; R } 1.45 \text { [2] }\end{array}$ \\
\hline${ }^{10}$ GIEAAASAIQGNVTIS ${ }^{25}$ & E2 & 32.4 & $\begin{array}{c}1500.7 / \\
1500.8\end{array}$ & $\begin{array}{l}\text { D } 1.15 \text { [1]; T } 0.99 \text { [1]; S } 2.04 \text { [2]; E } 2.02 \text { [2]; } \\
\text { G } 2.12 \text { [2]; A } 4.15 \text { [4]; V } 1.02 \text { [1]; I } 2.74 \text { [3] }\end{array}$ \\
\hline${ }^{16}$ SAIQGNVTSIHSLLDEGKQSLTKLA ${ }^{40}$ & E3 & 28.1 & $\begin{array}{l}2609.9 / \\
2609.7\end{array}$ & $\begin{array}{l}\text { D } 1.75 \text { [2]; T } 1.96 \text { [3]; S } 3.76 \text { [3]; E } 3.00 \text { [3]; } \\
\text { G } 2.11 \text { [2]; A } 2.16 \text { [2]; V } 1.03 \text { [1]; I } 1.44 \text { [2]; } \\
\text { L } 4.28 \text { [4]; H } 1.08 \text { [1]; K } 2.42 \text { [2] }\end{array}$ \\
\hline${ }^{46}$ SGSEAYQGVQQKWDATATELNNALQ ${ }^{80}$ & E5 & 26.9 & $\begin{array}{c}2708.9 / \\
2709.0\end{array}$ & $\begin{array}{l}\text { D } 2.95 \text { [3]; T } 1.86 \text { [2]; S } 1.66 \text { [2]; E } 6.81 \text { [6]; } \\
\text { G } 1.86 \text { [2]; A } 4.00 \text { [4]; V } 1.00 \text { [1]; L } 2.00 \text { [2]; } \\
\text { Y } 0.76[1] ; \text { K } 1.09[1]\end{array}$ \\
\hline${ }^{61}$ TATELNNALQNLARTISEAGQAMAS ${ }^{85}$ & E6 & 37.4 & $\begin{array}{c}2574.9 / \\
2574.6\end{array}$ & $\begin{array}{l}\text { D } 3.07 \text { [3]; T } 2.96 \text { [3]; S } 2.08 \text { [2]; E } 4.66 \text { [4]; } \\
\text { G } 0.92 \text { [1]; A } 6.27 \text { [6]; M } 0.46 \text { [1]; I } 0.92 \text { [1]; } \\
\text { L } 3.00[3] ; \text { R } 0.88[1]\end{array}$ \\
\hline
\end{tabular}




\begin{tabular}{|c|c|c|c|c|}
\hline${ }^{72}$ NLARTISEAGQAMASTEGNVTGMFA ${ }^{95}$ & E7 & 28.2 & $\begin{array}{c}2526.8 / \\
2526.6\end{array}$ & $\begin{array}{c}\text { D } 2.29 \text { [2]; T } 2.82 \text { [3]; S } 2.04 \text { [2]; E } 3.10 \text { [3]; } \\
\text { G } 2.98 \text { [3]; A 5.12 [5]; M 1.56 [2]; V 1.02 [1]; I 1.02 [1]; L } \\
0.89 \text { [1]; } \\
\text { F } 0.93 \text { [1]; R } 1.82 \text { [2] }\end{array}$ \\
\hline \multicolumn{5}{|c|}{$\begin{array}{l}\text { aConditions: Knauer, Eurospher- } 100 \mathrm{C}_{18} \text { column }(4.0 \times 250 \mathrm{~mm}), 5 \mathrm{~mm} \text { silica (pore size: } 300 \AA \text { ), } \\
\text { gradient elution: } 5-60 \% \mathrm{~B}, 35 \mathrm{~min} \text {, eluents: } 0.1 \% \mathrm{TFA} /(\mathrm{A}), 0.1 \% \mathrm{TFA} / \text { acetonitrile} / \text { water }=80 / 20 \mathrm{v} / \mathrm{v} \text { (B), flow rate: } 1.0 \mathrm{ml} / \mathrm{min} \text {, } \\
\text { detection: } \mathrm{l}=220,214 \mathrm{~nm} \\
\text { bESI-MS (acquired by Bruker Esquire } 3000+\text { ESI-MS). } \\
{ }^{c} \text { Hidrolysis }\left(6 \mathrm{M} \mathrm{HCl}, 110^{\circ} \mathrm{C}, 24-36 \mathrm{hrs} \text {, Asn and Gln determined as Asp and Glu) }\right.\end{array}$} \\
\hline
\end{tabular}

\section{Study populations}

15 volunteers, healthcare workers, (11 women, 4 men, age: 28-61 years) dealing with TB patients or with their test materials at the Department of Pulmonology at the University of Debrecen and 2 HCW workers with verified LTBI from Budapest (HCW-TB) as positive controls. b) 14 healthcare workers not being exposed to TB patients as negative controls (10 women, 4 men, age: 31 67 years)(HCW-C). All participants in the study have been BCGvaccinated in childhood.

\section{Ethical statement}

All members of the study population signed a written consent to take part in the study. The number of ethical permission to carry out the examination is 30052-2015 emitted by the local Committee of Ethics at the University of Debrecen.

\section{Sample handling}

$7 \mathrm{ml}$ of heparinized whole blood samples applicable for functional cellular tests were taken and used from every subject. The mononuclear cells (monocytes and lymphocytes) of blood were the targets of stimulation by TB-P and PPD [20].

a) Based on preliminary studies the final concentration of TB-P was $20 \mu \mathrm{g} / \mathrm{ml}$ solved in a culture medium (RPMI-1640 plus $10 \%$ FCS) and it was used as the specific stimulant. This dose of the peptides was not found cytotoxic on peripheral blood mononuclear cells (PBMC) of healthy donors [21].

b) The final concentration of Purified Protein Derivative (PPD) (Roche Diagnostics, Switzerland) was also $20 \mu \mathrm{g} / \mathrm{ml}$ solved in the culture medium (RPMI-1640 plus $10 \%$ FCS). This dose of PPD also was not found cytotoxic.

c) QuantiFERON-TB Gold In-Tube test (QFT) (Cellestis, Australia) was used according to the manufacturer's instructions. T-SPOT. TB ELISPOT assay was not used.

The verification of LTBI: was "classically" based on "positive" Mantoux and/or Quantiferon tests and a "negative" radiological lung result. Patients with active tuberculosis were ruled out from this study.

\section{Cytokine measurement}

The amount of tumour necrosis TNF- $\alpha$ was determined by the commercial ELISA kit purchased form R\&D Systems (San Francisco, USA) carried out according to the description of the kit.

\section{Culturing and stimulation of the whole blood cells}

The cocktail of TB peptides and PPD were used as stimulants for the whole blood samples of HCW-TB and HCW-C groups simultaneously as follows:

$1 \mathrm{ml}$ of fresh heparinized blood (in duplicated tubes)

Activating agents:

a) PPD: $20 \mu \mathrm{g} / \mathrm{ml}$;

b) TB peptides: $20 \mu \mathrm{g} / \mathrm{ml}$;

c) Control: the same volume of culture medium (RPMI-1640 plus $10 \% \mathrm{FCS})$

Incubation: 20 hours at 37o C grade, 5\% CO2 milieu

The measurement of TNF- $\alpha$ by ELISA occurred in the centrifuged plasma samples.

\section{The diagnosis of LTBI established by the calculation of Index of Stimulation}

Index of Stimulation (IS): TNF $\alpha(\mathrm{pg} / \mathrm{ml}) \mathrm{TB} / \mathrm{TNF} \alpha(\mathrm{pg} / \mathrm{ml})$ PPD.

The diagnosis of existing LTBI: IS $>1.50$.

This value was chosen after the analysis of the data of Table 2 , as the value of 1.61 was not only clinically positive for LTBI but also by QFT. Thus, the value of 1.50 can be a safe border to separate the "positive" and "negative" cases.

No LTBI: IS $<1.50$

Borderline: IS = 1.50 (clinically "positive")

The name of assay: "TNF $\alpha$-IS Test" (Tumour Necrosis Factor $\alpha$ - Index of Stimulation Test)

\section{The results of QFT measurements}

The QFT tests were used according to the protocol at the Department of Microbiology carried out in parallel to "TNF $\alpha$ - IS Test".

The evaluation of QFT results:

IFN $\gamma<0.35$ IU: negative

IFN $\gamma>0.35$ IU: positive 


\section{Statistical analysis}

The Spearman's coefficient of correlation ( $r$ ) was calculated between the results of the "TNF $\alpha$ - IS" and QFT tests.

$\mathrm{P}<0.05$ was considered significant.

\section{Results}

Comparison of results on TNF- $\alpha$ release induced by PPD and TB peptides with the results of QuantiFERON test in blood samples of HCW-TB

In a series of preliminary experiments we investigated the blood samples of two healthcare workers as "positive" controls with existing LTBI from the National Tuberculosis Centre of Budapest dealing with TB patients for decades in comparison with two healthy "negative" control subjects. In these studies we found the dose of $20 \mu \mathrm{g} / \mathrm{ml}$ of peptide cocktail/protein to be the optimal amount for stimulations by both TB peptides and PPD. In addition, it became also clear that the changes found by measurement of TNF- $\alpha$ were only able to reflect LBTI compared to IL - $1 \beta$, IL-6 and IL-10. Furthermore, the "20 hours" as incubation time was also more practical than that of 4,12 and 24 hours. (Data are not shown).

Table 2: Comparison of results on TNF- $\alpha$ release induced by PPD and TB peptide cocktail with the results of QuantiFERON test in blood samples of HCW-TB

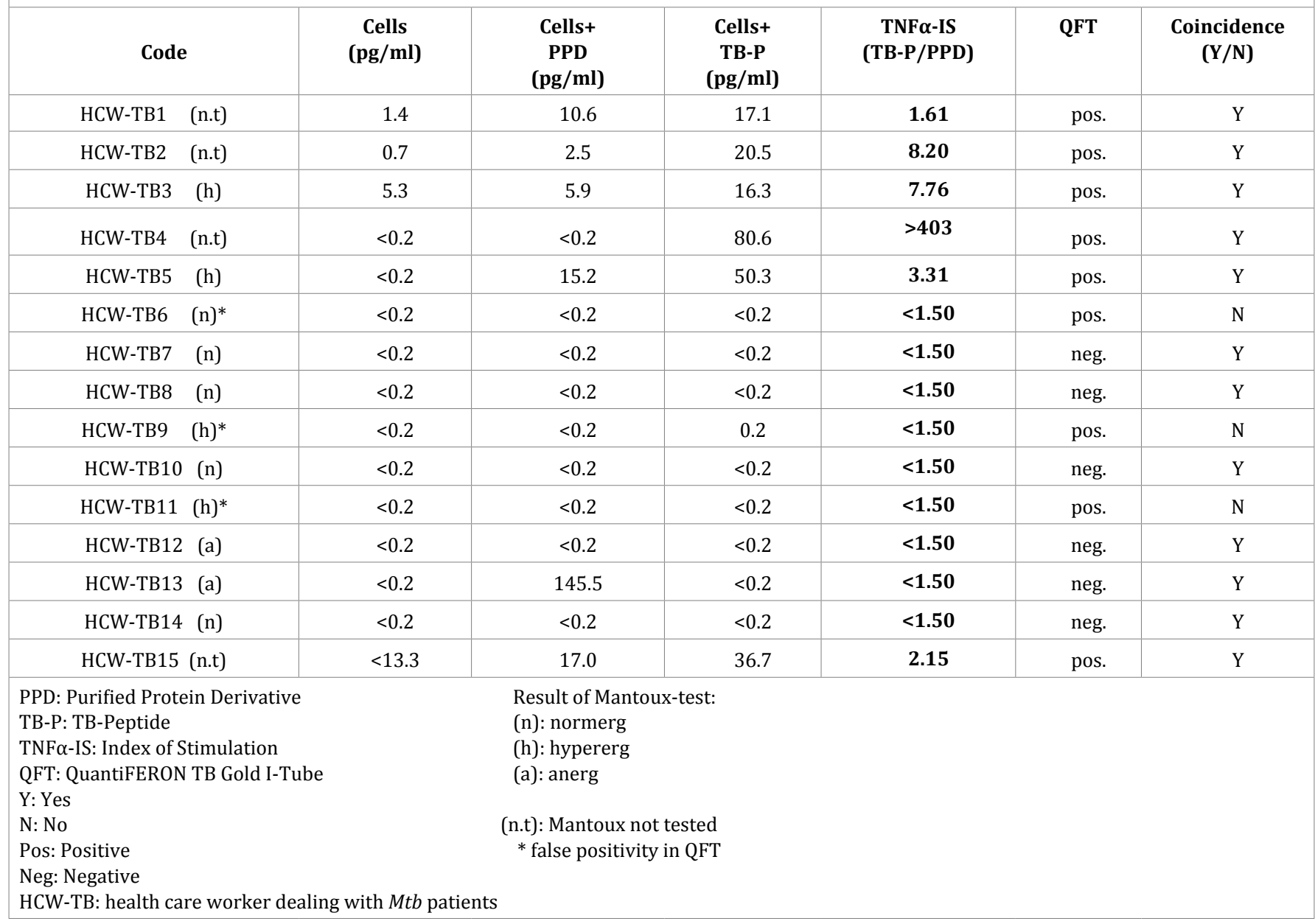

Table 2, shows the coincidence between the data of TNF- $\alpha$ measurements and Quantiferon test in the case of $15 \mathrm{HCW}$ TB patients. Based on 13 YES (Y) and 3 NO (N), the "value of coincidence" (V.C) was $80 \%$. Namely, among the healthcare workers dealing with Mtb patients HCW-TB6, HCW-TB9 and HCWTB11 were found to be "positive" by QFT for LTBI, but they were "negative" using the TNF- $\alpha$-IS Test. The Spearman's coefficient of correlation $r=0.667(P=0.007)$ was also highly significant between the results of two methods, showing a remarkable accordance. However, it was very important that the accordance was highly not perfect between the two methods. The number of positive cases was higher measured by QFT $(9 / 15)$ than by TNF$\alpha$-IS Test (6/15). The 3 persons (HCW-TB6, HCW-TB9 and HCWTB11) not showing the coincidence have been clinically further tested for LTBI, and they were found to be "negative". Thus, their QFT results could be regarded as "false positive laboratory findings". Two of these individuals showed hyperactivity and one normal Mantoux reaction. 


\section{Comparison of results on TNF- $\alpha$ release induced by PPD and TB peptides with the results of QuantiFERON test in blood samples of HCW-C}

All the 14 members of control subjects (HCW-C) were negative by both methods for LTBI. The "values of coincidence" (V.C) was $100 \%$ (Table 3).

Table 3: Comparison of the results on TNF- $\alpha$ release induced by PPD and TB peptide cocktail with the results of QuantiFERON test in blood samples of HCW-C

\begin{tabular}{|c|c|c|c|c|c|c|}
\hline Code & $\begin{array}{c}\text { Cells } \\
(\mathrm{pg} / \mathrm{ml})\end{array}$ & $\begin{array}{c}\text { Cells+PPD } \\
(\mathrm{pg} / \mathrm{ml})\end{array}$ & $\begin{array}{c}\text { Cells + TBP } \\
(\mathrm{pg} / \mathrm{ml})\end{array}$ & $\begin{array}{l}\text { TNF } \alpha-I S \\
(\mathrm{pg} / \mathrm{ml})\end{array}$ & QFT & $\begin{array}{c}\text { Coincidence } \\
(\mathrm{Y} / \mathrm{N})\end{array}$ \\
\hline HCW-C1 & $<0.2$ & $<0.2$ & $<0.2$ & $<1.50$ & neg. & $\mathrm{Y}$ \\
\hline $\mathrm{HCW}-\mathrm{C} 2$ & $<0.2$ & $<0.2$ & $<0.2$ & $<1.50$ & neg. & $\mathrm{Y}$ \\
\hline $\mathrm{HCW}-\mathrm{C} 3$ & $<0.2$ & $<0.2$ & $<0.2$ & $<1.50$ & neg. & $\mathrm{Y}$ \\
\hline $\mathrm{HCW}-\mathrm{C} 4$ & $<0.2$ & $<0.2$ & $<0.2$ & $<1.50$ & neg. & $\mathrm{Y}$ \\
\hline $\mathrm{HCW}-\mathrm{C} 5$ & $<0.2$ & 3.5 & 0.8 & $<1.50$ & neg. & $\mathrm{Y}$ \\
\hline HCW-C6 & $<0.2$ & $<0.2$ & $<0.2$ & $<1.50$ & neg. & $\mathrm{Y}$ \\
\hline $\mathrm{HCW}-\mathrm{C} 7$ & 9.8 & 4.9 & 4.3 & $<1.50$ & neg. & Y \\
\hline HCW-C8 & 15.3 & 13.3 & 14.3 & $<1.50$ & neg. & $\mathrm{Y}$ \\
\hline HCW-C9 & $<0.2$ & 4.6 & 0.9 & $<1.50$ & neg. & Y \\
\hline HCW-C11 & $<0.2$ & 46.4 & 6.6 & $<1.50$ & neg. & $\mathrm{Y}$ \\
\hline HCW-C12 & $<0.2$ & 3.6 & $<0.2$ & $<1.50$ & neg. & $\mathrm{Y}$ \\
\hline HCW-C13 & 39.0 & 7.9 & 7.9 & $<1.50$ & neg. & $\mathrm{Y}$ \\
\hline HCW-C14 & 3.3 & 3.6 & 2.9 & $<1.50$ & neg. & $\mathrm{Y}$ \\
\hline \multicolumn{7}{|c|}{$\begin{array}{l}\text { PPD: Purified Protein Derivative } \\
\text { TB-P: TB-Peptide } \\
\text { TNF } \alpha \text {-IS: Index of Stimulation } \\
\text { QFT: QuantiFERON TB Gold I-Tube } \\
\text { Y: Yes } \\
\text { Neg: Negative } \\
\text { HCW-C: health care worker control not dealing with } M t b \text { patients }\end{array}$} \\
\hline
\end{tabular}

\section{Discussion}

In the last years it became clear that the IGRA assays based on IFN $\gamma$ release to diagnose LTBI performed insufficiently [7,10\&11]. There is a need for new differential diagnostic methods. In the current work we developed a new approach and methodical principle for this purpose preserving one crucial element of QFT, namely, we used also a mixture of ESAT- 6 and CFP-10 overlapping peptides to stimulate the mononuclear cells of whole blood, but only for 20 hours. At the same time, we are aware of the weakness of this study, not having a great number of determinations yet, being only at the beginning of a promising work.

In the new assay four elements have been introduced and applied: a) the release of TNF- $\alpha$ induced by TB-P was measured; b) in parallel, also PPD was used for cell stimulation as control; c) an Index of Stimulation named "IS" was calculated according to the formula: TNF- $\alpha$ TB-peptide $(\mathrm{pg} / \mathrm{ml}) / T N F-\alpha$ PPD (pg/ $\mathrm{ml}$ )/ d.) if the IS value was higher than 1.50 (IS > 1.50), the diagnosis of LTBI was established according to the data of Table 2. We tested the two methods on healthcare workers dealing (HCW-TB) and not dealing with tuberculosis patients (HCW-C).
Comparing the results of QFT and "TNF- $\alpha$ - IS" tests in HCW-TB subjects, the "value of coincidence" (VC) was rather good, $80 \%$. In addition, the Spearman's coefficient of correlation $r=0.667$ ( $P$ $=0.007$ ) was also highly significant between the results of two methods showing a remarkable parallel outcome. However, it was of note that in this group the rate of positivity was $9 / 15$ by QFT, whereas it was $6 / 15$ using the "TNF- $\alpha$ IS" test. Clinically, the 3 persons of discordance were negative for LTBI, thus they could be regarded as "false positive" cases found by QFT. Therefore, the great individual clinical importance of this observation is that these subjects would still get the chance for a biological therapy according to the "TNF- $\alpha$-IS Test". This result shows that the specificity of the new measurement seems to be higher than that of QFT or Mantoux reaction. However, using the skin test, two of the three "false positive" patients gave "hyperergic" reactions. This phenomenon could be explained by the common IFN $\gamma$ dependent mechanism of QFT and Mantoux tests [22]. At the same time, this fact also could reflect the different pathway of the "TNF- $\alpha$ " based approach. From these data the "values of coincidence"(V.C.) were as follows: 


$$
\begin{aligned}
& \text { V.C. = Mantoux - “TNF- } \alpha \text {-IS": } 66.66 \% \text {; } \\
& \text { V.C. = Mantoux-QFT: } 85.7 \%
\end{aligned}
$$

In the new principle PPD was introduced as the "background" in the comparisons to the specific effects of TB-peptides. However, in Hungary but also in a rather great part of the world the effects of BCG vaccinations is rather strong in the majority of population. In the new assay, PPD as a standard basic stimulant can show the influence of the earlier BCG vaccinations reflected as a nonspecific release of TNF- $\alpha$. Finally, calculating the IS values this background effect can be eliminated from the results of TB-P giving the values of true Mtb specificity. This approach was able to differentiate between the specific (TB-P) and not specific (PPD) effects pointing out also the "false positive" part of QFT results.

There is a long list of articles describing the increased production of TNF- $\alpha$ during LTBI [12-16]. Therefore, the choice of its measurement as a marker for the laboratory diagnosis of LTBI seems to be relevant. In addition, there can be still another theoretic advantage of "TNF- $\alpha$-IS Test" to exclude LTBI before the "TNF- $\alpha$ targeted" biologic therapeutics [23\&24]. We do think that the "TNF- $\alpha$ " character and the improved specificity of the new test may suggest a simple practical clinical message: if the IS value is less than 1.50, the TNF- $\alpha$ targeted biologic therapy can be started."

In our current work "TNF $\alpha$ - IS Test" was found superior than QFT in diagnosing LBTI in healthcare workers. These people represent that population which permanently would need a safe laboratory test for the diagnosis of LTBI [9\&11]. The "TNF $\alpha$ - IS Test" can be offered also for them.

In conclusion, we present here a new principle for a laboratory assay: the "TNF $\alpha$ - IS Test" developed for the laboratory diagnosis of LTBI and found superior compared to the QFT measurements. The efficacy of test was verified on healthcare workers dealing and not dealing with Mtb patients. Although the number of determinations is still not great. However, in further studies the theoretical novelties in the principle of method: the calculation of IS from the TNF- $\alpha$-TB-P/ TNF- $\alpha-$ PPD values can mean a progress in the individual laboratory diagnosis of LTBI in patients before biological therapies and in the survey of healthcare workers dealing with $M t b$ patients.

\section{Acknowledgments}

We thank the healthcare workers included Dr. Nóra Szabó for their participation in the study. In the laboratory experiments Dr. Sándor Baráth, Dr. György Lustyik and Dr. Árpád Czéh did an excellent work. The synthesis of the peptides was supported by OTKA (K 104275, K 104385). This study was also supported by the Foundations „Hörgőrák” and „Immunológiai XXI Debrecen”. The authors are very thankful Professor Liana Tsenova MD (New York) for the corrections in the manuscript.

\section{Author Disclosure Statement}

This study was published in any scientific journals yet. The authors declare that no competing interest exists among them.

\section{Authorship}

Significant contribution: S S, ZS P, I K, F H. M SZ.

Contribution to the final version: $\mathrm{K} \mathrm{H}, \mathrm{SZ} \mathrm{B}$.

\section{References}

1. Doherty M, Wallis RS and Zumla A. WHO-Tropical Disease Research/ European Commission joint expert consultation group. Biomarkers for tuberculosis disease status and diagnosis. Curr Opin Pulm Med. 2009;15(3):181-187.

2. Lienhardt C, Fielding K, Hane AA, Niang A, Ndao CT and Karam F. et al. Evaluation of the prognostic value of IFN-gamma release assay and tuberculin skin test in household contacts of infectious tuberculosis cases in Senegal. PLoS ONE. 2010;5(5):e10508. Doi: 10.1371/journal. pone.0010508.

3. Farhat M, Greenaway C, Pai M and Menzies D. False-positive tuberculin skin tests: what is the absolute effect of BCG and non-tuberculous mycobacteria. Int J Tuberc Lung Dis. 2006;10(11):1192-1204.

4. Behr MA, Wilson MA, Gill WP, Salamon H, Schoolnik GK and Rane S. et al. Comparative genomics of BCG vaccines by whole-genome DNA microarray. Science. 1999;284(5419):1520-1523. Doi: 10.1126/ science.284.5419.1520.

5. Renshaw PS, Panagiotidou P, Whelan A, Gordon SV, Hewinson RG and Williamson RA. et al. Conclusive evidence that the major T-cell antigens of the Mycobacterium tuberculosis complex ESAT- 6 and CFP-10 form a tight, 1:1 complex and characterization of the structural properties of ESAT-6, CFP-10, and the ESAT-6, CFP-10 complex. Implications for pathogenesis and virulence. J Biol Chem. 2002;277(24):21598-21603. Doi: $10.1074 /$ jbc.M201625200.

6. Richeldi L. An Update on the Diagnosis of Tuberculosis Infection. Am J Respir Crit Care Med. 2006;174(7):736-742.

7. Pai M, Denkinger CM, Kik SV, Rangaka MX, Zwerling A and Oxlade O. et al. Gamma interferon release assays for detection of Mycobacterium tuberculosis infection. Clin Microbiol Rev. 2014;27(1):3-20. Doi: Doi 10.1128/Cmr.00034-13.

8. Kang YA, Lee HW, Yoon HI, Cho B, Han SK and Shim YS. et al. Discrepancy between the tuberculin skin test and the whole blood interferon $\gamma$ assay for the diagnosis of latent tuberculosis infection in an intermediate tuberculosis burden country. JAMA. 2005;293(22):2756-2761. DOI:10.1001/jama.293.22.2756.

9. Yoshiyama T, Harada N, Higuchi H, Sekiya Y and Uchimura K. Use of the QuantiFERON-TB Gold test for screening tuberculosis contacts and predicting active disease. Int J Tuberc Lung Dis. 2010;14(7):819-827.

10. Costantino F, de Carvalho Bittencourt M, Rat AC, Loeuille D, Dintinger $\mathrm{H}$ and Béné MC. et al. Screening for latent tuberculosis infection in patients with chronic inflammatory arthritis: discrepancies between tuberculin skin test and interferon $\gamma$ release assay results. J Rheumatol. 2013;40(12):1986-1993. Doi: 10.3899/jrheum.130303.

11. Lamberi M, Uccello R, Lourdes Monaco MGL, Muoio M, Feola D and Sannolo N. et al. Tuberculin skin test and Quantiferon test agreement and influencing factors in tuberculosis screening of health care workers: a systemic review and meta-analysis. J Occup Med Tox. 2015;10:2. Doi: 10.1186s12995-015-0044-y. 
12. Sutherland JS, de Jong BC, Jeffries DJ, Adetifa IM and Ota MOC. Production of TNF- $\alpha$, IL-12(p40) and IL-17 can discriminate between active TB disease and latent infection in West African cohort. PLoS ONE. 2010;5(8):e12365. Doi: 10.1371/journal.pone.0012365.

13. Roca FJ and Ramakrishnan L. TNF dually mediates resistance and susceptibility to mycobacteria via mitochondrial reactive oxygen species. Cell. 2013;153(3):521-534. Doi: 10.1016/j.cell.2013.03.022.

14. Won EJ, Choi JH, Cho YN, Jin HM, Kee HJ and Park YW. et al. Biomarkers for discrimination between latent tuberculosis infection and active tuberculosis disease. J Infect. 2017;74(3):281-93. Doi: 10.1016/j. jinf.2016.11.010.

15. Nausch N, Lundtof C, Schulz G, Henckel H, Mayatepek E and Fleischer B. et al. Multiple cytokines for the detection of Mycobacterium tuberculosis infection in children with tuberculosis. Int J Tuberc Lung Dis. 2017;21(3):270-277. Doi: 10.5588/ijtld.16.0351.

16. Peddireddy V, Doddam N and Ahmed N. Mycobacterial dormancy systems and host responses in tuberculosis. Front Immunol. 2017;8:84. Doi 10.3389/fimmun. 2017.00084.

17. Camlar SA, Makay B, Appak O, Appak YC, Esen N and Günay T. et al. Performance of tuberculin skin test and interferon gamma assay for the diagnosis of latent tuberculosis infection in juvenile idiopathic arthritis. Clin Rheumatol. 2011;30(9):1189-1193. Doi: 10.1007/ s10067-011-1724-3.

18. Bősze Sz and Hudecz F. Proteins and peptides for the immunodiagnosis and therapy of Mycobacterium tuberculosis infections. In: Specialist Periodical Reports- Amino Acids, Peptides and Proteins. (Eds.: Ryadnov, M., Hudecz, F.) 40:146-198.2016;ISBN: 978-78262-059-4. The Royal Society of Chemistry, Cambridge, UK.
19. Szabados H, Uray K, Majer Z, Silló P, Kárpáti S and Hudecz F. Characterization of desmoglein-3 epitope region peptides as synthetic antigens: analysis of their in vitro T cell stimulating efficacy, cytotoxicity, stability, and their conformational features. J Pept Sci. 2015;21(9):731-742. Doi:10.1002/psc.2800.

20. de Paus RA, van Meijgaarden KE, Prins C, Kamphorst MH, Arend SM and Ottenhoff THM. Immunological characterization of latent tuberculosis infection in a low endemic country. Tuberculosos (Edinb). 2017;106:62-72.Doi: 10.1016/j.tube.2017.07.001.

21. Mosmann T. Rapid colorimetric assay for cellular growth and survival: application to proliferation and cytotoxicity assays. J Immunol. Methods. 1983;65(1-2):55-63.

22. Black GF, Fine PEM, Warndorff DK, Floyd S, Weir RE and Blackwell JM. et al. Relationship between IFN-gamma and skin test responsiveness to Mycobacterium tuberculosis PPD in healthy, non BCG vaccinated young adults in Northern Malawi. Int J Tuberc Lung Dis. 2001;5(7):664-672.

23. Hatemi G and Yazici H. Tuberculosis screening before and during treatment with tumor necrosis factor antagonists: something old, something new. J Rheumatol. 2013;40(12):1938-1940. Doi:10.3899/ jhreum.131218.

24. Tsenova L, O’Brien P, Holloway J, Peixoto B, Soteropoulos P and Fallows D. et al. Etanercept exacerbates inflammation and pathology in a rabbit model of active pulmonary tuberculosis. J Interferon Cytokine Res. 2014;34(9):716-726. Doi: 10.1089/jir.2013.0123. 